\title{
MODE OF ACTION OF OESTROGEN IN MAINTAINING THE FUNCTIONAL LIFE OF CORPORA LUTEA IN SHEEP
}

\author{
R. DENAMUR*, J. MARTINET* AND R. V. SHORT $\dagger$ \\ *C.N.R.Z., Fouy-en-Fosas, Seine-et-Oise, France, and \\ $\dagger$ A.R.C. Unit of Reproductive Physiology and Biochemistry, and \\ Department of Veterinary Clinical Studies, University of Cambridge
}

(Received 16th Fanuary 1970)

\begin{abstract}
Summary. Twice-daily intramuscular injections of $0.5 \mathrm{mg}$ oestradiol benzoate, starting on Day 3 of the cycle, were able to prolong the life of the corpora lutea in sheep, as judged by their weight, their DNA and RNA content, and the progesterone concentration in ovarian vein blood. This luteotrophic effect persisted even when the pituitary stalks of the animals were sectioned, but it was abolished when the animals were hypophysectomized.

Four possible sites of oestrogen action were considered; the hypothalamus, the pituitary, the corpus luteum and the uterus. It was concluded that oestrogen is luteotrophic principally because of its action on the uterus, where it seems to interfere with the normal luteolytic mechanism.
\end{abstract}

\section{INTRODUCTION}

The functional life of the cyclical corpus luteum (cL) in sheep can be prolonged in four ways; by pregnancy (Moor, 1968), by hysterectomy (Denamur, Martinet \& Short, 1966; Ginther, 1967; Moor, Hay, Short \& Rowson, 1970), by oestrogen injections (Denamur \& Mauléon, 1963; Piper \& Foote, 1968) and by infusions of luteinizing hormone (Karsch, Noveroske, Roche \& Nalbandov, $1969 \mathrm{a}, \mathrm{b}$ ). The fact that pregnancy, hysterectomy and hormonal therapy have similar effects on the GL suggests that they could have a similar mode of action. The effects of pregnancy and hysterectomy have both been attributed to the removal of the uterine luteolytic stimulus; the luteotrophic effects of oestrogens could be due to a number of factors acting separately or in concert, namely (1) an action on the hypothalamus, causing increased pituitary luteinizing hormone (LH) or prolactin secretion, (2) a direct luteotrophic action on the CL itself, and (3) an action on the endometrium, inhibiting luteolysin production. The purpose of the present study has been to evaluate these various possibilities.

\section{Experimental animals}

\section{MATERIALS AND METHODS}

Ewes of the Prealpes du Sud breed, aged between 10 and 22 months, were used. Animals were checked for oestrus twice daily with a vasectomized ram. 
The first day of oestrus was considered as Day 1 of the cycle. The ewes were divided into six experimental groups, as follows:

Group 1. Five normal animals were killed on Day 12 of the cycle.

Group 2. Four animals received twice-daily intramuscular (i.m.) injections of $0.5 \mathrm{mg}$ oestradiol benzoate (Roussel). Treatment was begun on Day 3 of the cycle, and was continued until Day 20.

Group 3. Five animals were subjected to the same oestrogenic treatment as those in Group 2 but, in addition, they were hypophysectomized on the day of ovulation.

Group 4. Eleven animals were subjected to section of their pituitary stalks on Day 2 of the cycle, and were subsequently killed on Day 16, 17 or 20.

Group 5. Four animals were subjected to section of their pituitary stalks as in Group 4 and, in addition, they received twice-daily i.m. injections of $0.5 \mathrm{mg}$ oestradiol benzoate from Day 3 to Day 20.

Group 6. Six animals were hysterectomized and their pituitary stalks were sectioned on Day 2 of the cycle. They were killed on Day 20.

\section{Surgical procedures and histological control}

Anaesthesia was induced with a mixture of sodium thiopentone and pentobarbitone (Abbott) given intravenously and maintained by inhalation of a nitrous oxide: oxygen: halothane mixture (Avlon).

Hypophysectomy was carried out by the parapharyngeal route and removal of the pituitary gland itself was performed with the aid of a set of curettes of various shapes. At the end of the operation, the walls of the sella turcica were swabbed with $2 \%$ phenol, and then frozen with a jet of 'Spra-freeze' to $-50^{\circ} \mathrm{F}$. These procedures were repeated several times in an effort to destroy any possible cellular remnants of pituitary tissue in the region of the venous sinuses.

On the 20th day after oestrus, the hypophysectomized animals were killed and their heads were perfused with $10 \%$ formalin injected into the carotid arteries. Several hours later, the tissue in the sella turcica was dissected out from each skull and placed in Bouin's fluid. Serial sections were subsequently cut at $10 \mu$, and one in ten was examined histologically. Any animal with a trace of pituitary tissue remaining in the sella was discarded. However, pars tuberalis tissue was present in all animals. Section of the pituitary stalk was also carried out by the parapharyngeal route. It was completed by the removal of a small fragment of the anterior part of the adenohypophysis, followed by the insertion of a plaque of aureomycin-impregnated wax between the cut ends of the stalk. This was sufficient to prevent the revascularization of the anterior pituitary by hypothalamic vessels for the limited duration of these experiments. Infarcts and other lesions of the pituitary produced by this technique are sometimes very pronounced, which may account for the poor secretory activity of the isolated gland noted in some of our experiments.

At the termination of the hypophysectomy or stalk-section operations, an i.m. injection of $10 \mathrm{mg}$ cortisol was given and the ewes subsequently received a daily dose of $20 \mathrm{mg}$ cortisol, divided between two i.m. injections.

Hysterectomy was carried out by removing half the cervix, the body and horns of the uterus, and the oviducts. 
Measurement of progesterone concentrations in ovarian venous blood

Before slaughter, the animals were anaesthetized by the procedure described above, and ovarian vein blood was collected by the technique of Short, McDonald \& Rowson (1963). The heparinized blood was centrifuged for 20 min at $1800 \mathrm{~g}$, and the plasma stored at $-20^{\circ} \mathrm{C}$ until it could be assayed. Progesterone was determined by the gas chromatographic technique of Schomberg, Coudert \& Short (1967) and all results have been corrected for extraction losses by means of an internal isotope standard of $\left[{ }^{3} \mathrm{H}\right]$ progesterone.

Determination of the fresh weight of the corpus luteum, and its nucleic acid content

After collecting the ovarian vein .blood, and whilst the animal was still anaesthetized, the ovary containing the cL was removed. The CL was rapidly dissected out and weighed. A piece was taken for nucleic acid estimations, and the remainder was used for histological studies or for progesterone estimations.

The measurement of ribonucleic acid (RNA) and desoxyribonucleic acid (DNA) was carried out according to the procedure recently described by Gaye \& Denamur (1970) for the mammary gland. After several extractions with cold $10 \%$ trichloroacetic acid, and de-fatting of the tissue, it was subjected to alkaline hydrolysis $\left(\mathrm{NaOH}, 0.3 \mathrm{~m}\right.$, at $37^{\circ} \mathrm{C}$ for $24 \mathrm{hr}$ ), followed by separation of the ribonucleotides on a column of Dowex 1-X8 (formate). The nucleotides were estimated quantitatively in a spectrophotometer by means of their molar extinction coefficient at 260 and $280 \mathrm{~m} \mu$, and their sum allowed one to calculate the amount of RNA in terms of $\mu \mathrm{g}$ of phosphate. The amount of DNA, expressed as $\mu \mathrm{g}$ phosphate, was determined by the amount of guanine and adenine liberated following acid hydrolysis with $\mathrm{HClO}_{4}\left(0.5 \mathrm{M}\right.$, at $100^{\circ} \mathrm{C}$ for $1 \mathrm{hr}$ ), after separation on a column of amberlite IR $120\left(\mathrm{H}^{+}\right)$.

\section{RESULTS}

Effects of injections of oestradiol on the corpus luteum of cycling ewes

Oestradiol benzoate injected from Days 3 to 20 in a dose of $2 \times 0.5 \mathrm{mg} / \mathrm{day}$ (Group 2) produced a number of structural and functional modifications of the CL (see Table 1). The CL did not regress between Days 15 and 17, as it

TABLE 1

INFLUENGE OF OESTRADIOL BENZOATE ON THE WEIGHT AND NUCLEIC ACID GONTENT OF THE CORPUS LUTEUM

\begin{tabular}{|c|c|c|c|c|}
\hline Experiment & $\begin{array}{l}\text { Weight of } \\
C L(m g)\end{array}$ & $\begin{array}{l}\text { Content of } \\
D \mathcal{N} A(\mu g)\end{array}$ & $\begin{array}{l}\text { Content of } \\
R \mathcal{N} A(\mu g)\end{array}$ & $\underset{\text { ratio }}{R \mathcal{N} A: D \mathcal{N} A}$ \\
\hline $\begin{array}{l}\text { Group } 1 \\
\text { Day } 12 \text { of normal cycle } \\
\text { (Five animals) }\end{array}$ & $\begin{array}{l}724 \cdot 8 \\
\pm 83 \cdot 9\end{array}$ & $\begin{array}{l}144 \cdot 6 \\
\pm 12 \cdot 7\end{array}$ & $\begin{array}{l}234 \cdot 4 \\
\pm 35 \cdot 2\end{array}$ & $\begin{array}{l}1 \cdot 60 \\
\pm 0 \cdot 19\end{array}$ \\
\hline $\begin{array}{l}\text { Group } 2 \\
\text { Day } 20 \text { of cycle following } \\
\text { treatment with oestradiol } \\
\text { benzoate from Days } 3 \text { to } \\
20 \\
\text { (Four animals) }\end{array}$ & $\begin{array}{l}732 \cdot 1 \\
\pm 53\end{array}$ & $\begin{array}{l}209 \\
\pm 10\end{array}$ & $\begin{array}{l}267.9 \\
\pm 15 \cdot 7\end{array}$ & $\begin{array}{l}1.26 \\
\pm 0.01\end{array}$ \\
\hline
\end{tabular}


would have done in a normal cycle. The weight of the cL on Day 20 was not significantly different from that of normal CL on Day 12 (Group 1), the time when they are maximally developed. The amount of RNA in these CL maintained by oestradiol was also similar to that in normal cL on Day 12, but the

TABLE 2

INFLUENCE OF OESTRADIOL BENZOATE ON THE PROGESTERONE GONCENTRATION IN OVARIAN VEIN BLOOD

\begin{tabular}{|c|c|c|c|}
\hline \multicolumn{2}{|c|}{ Day 12 of normal cycle } & \multicolumn{2}{|c|}{$\begin{array}{l}\text { Day } 20 \text { of cycle after treatment with } \\
\text { oestradiol benzoate from Days } 3 \text { to } 20\end{array}$} \\
\hline Ewe No. & Progesterone concentration & Ewe No. & Progesterone concentration \\
\hline $\begin{array}{l}6453 \\
6456 \\
7073 \\
6293\end{array}$ & $\begin{array}{r}170 \cdot 3 \\
44 \cdot 8 \\
69 \cdot 5 \\
138\end{array}$ & $\begin{array}{l}6426 \\
6499 \\
6452 \\
6095\end{array}$ & $\begin{array}{l}107 \cdot 3 \\
176 \cdot 5 \\
158 \\
148 \cdot 8\end{array}$ \\
\hline
\end{tabular}

Results expressed as $\mu$ g progesterone $/ 100 \mathrm{ml}$ plasma.

amount of DNA was slightly increased, which produced a lower RNA: DNA ratio than in normal Day-12 cL. These oestrogen-maintained cL also continued to secrete normal amounts of progesterone; the values shown in Table 2 do not differ significantly from those on Day 12 of the cycle.

Effects of injections of oestradiol on the corpus luteum of ewes hypophysectomized on the day of ovulation

Oestradiol benzoate administered from the day after hypophysectomy until Day 20 (Group 3) did not prolong the life of the cL, which was incompletely developed following the hypophysectomy (Denamur, 1968). The weights of

TABLE 3

INFLUENGE OF PITUITARY STALK SEGTION ON DAY 2 OF THE GYGLE ON THE PROGESTERONE CONGENTRATION IN OVARIAN VEIN BLOOD

\begin{tabular}{|c|c|c|c|c|c|}
\hline \multicolumn{2}{|c|}{$\begin{array}{c}\text { Day } 12 \text { of cycle } \\
\text { following stalk } \\
\text { section }\end{array}$} & \multicolumn{2}{|c|}{$\begin{array}{c}\text { Day } 16 \text { of cycle } \\
\text { following stalk } \\
\text { section }\end{array}$} & \multicolumn{2}{|c|}{$\begin{array}{l}\text { Day } 17 \text { of cycle } \\
\text { following stalk } \\
\text { section }\end{array}$} \\
\hline Ewe $\mathcal{N} o$. & $\begin{array}{l}\text { Progesterone } \\
\text { concentration }\end{array}$ & Ewe $\mathcal{N} o$. & $\begin{array}{l}\text { Progesterone } \\
\text { concentration }\end{array}$ & Ewe No. & $\begin{array}{l}\text { Progesterone } \\
\text { concentration }\end{array}$ \\
\hline $\begin{array}{l}6421 \\
6143 \\
6507 \\
7116 \\
7268\end{array}$ & $\begin{array}{c}93 \cdot 7 \\
141 \cdot 1 \\
85 \cdot 6 ; 58 \cdot 7 \\
109 \cdot 8 \\
142 \cdot 6\end{array}$ & $\begin{array}{l}6441 \\
6082\end{array}$ & $\begin{array}{l}<0.2 \\
<1.3\end{array}$ & $\begin{array}{l}7256 \\
7108\end{array}$ & $\begin{array}{l}<0.3 \\
<0.5\end{array}$ \\
\hline
\end{tabular}

Results expressed as $\mu$ g progesterone/100 $\mathrm{ml}$ plasma.

the GL in three of the animals on Day 20 were 33,35 and $76 \mathrm{mg}$ and in two other animals the cL had completely disappeared. As a result of this marked luteal regression, there was no point in carrying out the nucleic acid or progesterone determinations. 


\section{TABLE 4}

INFLUENGE OF PITUITARY STALK SEGTION ON DAY 2 OF THE GYCLE ON THE WEIGHT AND NUGLEIC AGID GONTENT OF THE GORPUS LUTEUM

\begin{tabular}{|c|c|c|c|c|}
\hline $\begin{array}{c}\text { Stage of } \\
\text { cycle }\end{array}$ & $\begin{array}{l}\text { Weight of } \\
C L(m g)\end{array}$ & $\begin{array}{l}\text { Content of } \\
D \mathcal{N A}(\mu g)\end{array}$ & $\begin{array}{l}\text { Content of } \\
R \mathcal{N A}(\mu g)\end{array}$ & $\begin{array}{c}R N A: D \mathcal{N A} \\
\text { ratio }\end{array}$ \\
\hline $\begin{array}{l}\text { Day } 12 \\
\quad \text { (Five animals) }\end{array}$ & $465 \cdot 5 \pm 34 \cdot 8$ & $104 \cdot 2 \pm 6 \cdot 4$ & $177 \cdot 8 \pm 12$ & $1.68 \pm 0.01$ \\
\hline $\begin{array}{l}\text { Day } 16 \\
\text { (Two animals) }\end{array}$ & $349 \cdot 3$ & $92 \cdot 9$ & $122 \cdot 9$ & $1 \cdot 31$ \\
\hline $\begin{array}{l}\text { Day } 17 \\
\quad \text { (Three animals) }\end{array}$ & $134 \cdot 1 \pm 27 \cdot 5$ & & $23 \cdot 6$ & 0.48 \\
\hline $\begin{array}{l}\text { Day } 20 \\
\quad \text { (One animal) }\end{array}$ & 46 & N.D. & N.D. & \\
\hline
\end{tabular}

* Measurements were carried out on only one CL; the other two had already regressed.

TABLE 5

WEIGHT AND NUGLEIC ACID GONTENT OF THE CORPUS LUTEUM OF ANIMALS SUBJEGTED TO STALK SECTION AND TREATED WITH OESTRADIOL BENZOATE, OR HYSTERECTOMIZED

\begin{tabular}{|c|c|c|c|c|}
\hline Experiment & $\begin{array}{l}\text { Weight of } \\
C L(m g)\end{array}$ & $\begin{array}{l}\text { Content of } \\
D \mathcal{N} A(\mu g)\end{array}$ & $\begin{array}{l}\text { Content of } \\
R \mathcal{N} A(\mu g)\end{array}$ & $\begin{array}{c}R \mathcal{N} A: D \mathcal{N} A \\
\text { ratio }\end{array}$ \\
\hline $\begin{array}{l}\text { Group } 5 \\
\text { Oestradiol benzoate } \\
\text { (four animals) }\end{array}$ & $\begin{array}{r}400 \cdot 1 \\
\pm 27 \cdot 5\end{array}$ & $\begin{array}{r}137 \cdot 6 \\
\pm 13 \cdot 1\end{array}$ & $\begin{array}{l}155.4 \\
\pm 9.3\end{array}$ & $\begin{array}{c}1.14 \\
\pm 0.001\end{array}$ \\
\hline $\begin{array}{l}\text { Group } 6 \\
\text { Hysterectomy } \\
\text { (six animals) }\end{array}$ & $\begin{array}{r}313.2 \\
\pm 28.4\end{array}$ & $\begin{array}{l}88 \cdot 7 \\
\pm 4\end{array}$ & $\begin{array}{l}102 \cdot 2 \\
\pm 8 \cdot 2\end{array}$ & $\begin{array}{r}1.14 \\
\pm 0.01\end{array}$ \\
\hline
\end{tabular}

\section{TABLE 6}

PROGESTERONE SEGRETION IN ANIMALS SUBJEGTED TO STALK SEGTION AND EITHER TREATED WITH OESTRADIOL BENZOATE, OR HYSTEREGTOMIZED

\begin{tabular}{c|c|c|c}
\hline \multicolumn{2}{c|}{ Oestradiol } & \multicolumn{2}{|c}{ Hysterectomy } \\
\cline { 3 - 4 } Ewe No. & $\begin{array}{c}\text { Progesterone } \\
\text { concentration }\end{array}$ & Ewe No. & $\begin{array}{c}\text { Progesterone } \\
\text { concentration }\end{array}$ \\
\hline 7714 & $39 \cdot 5$ & 6475 & $25 \cdot 2$ \\
6447 & $81 \cdot 8$ & 7190 & $12 \cdot 8$ \\
7069 & $107 \cdot 8$ & 7352 & $3 \cdot 0$ \\
7403 & $88 \cdot 3$ & 7392 & $4 \cdot 3$ \\
& & 6459 & $53 \cdot 4$ \\
\hline
\end{tabular}

Results expressed as $\mu$ g progesterone $/ 100 \mathrm{ml}$ plasma. 
Effects of injections of oestradiol following section of the pituitary stalk on Day 2 of the cycle

(a) Effects of pituitary stalk section alone. This brought about a number of structural and functional modifications of the CL (Group 4). Their secretory activity was practically normal on Day 12 , as judged by the progesterone concentrations in ovarian vein blood (see Table 3 ). This level of secretion was not maintained beyond Day 15 and by Day 17, progesterone was no longer measurable, which is in agreement with our previous work (Denamur et al., 1966). Once again this demonstrates that, in the presence of the uterus, section of the pituitary stalk does not maintain luteal progesterone secretion.

The results of this experiment, summarized in Table 4, also show that the weights of the CL of animals subjected to stalk section on Day 12 of the cycle were less than in the controls. Similarly, the quantity of DNA was also decreased, but the RNA : DNA ratio of 1.68 shows that the luteal cells still had a normal RNA content.

Stalk section carried out soon after ovulation, therefore, seems to limit the development of the $\mathrm{CL}$, although the progesterone concentration in ovarian vein blood, the histological appearance of the gland (Denamur et al., 1966) and the concentration of RNA all appeared normal.

(b) Administration of oestradiol following stalk section. Oestrogen injections given to animals subjected to stalk section (Group 5) allow the CL to survive up to Day 20 (see Table 5). Their weight and RNA content were slightly less than that of cL collected from animals subjected to stalk section on Day 12 of the cycle. On the other hand, the DNA content was elevated on Day 20, resulting in a diminished RNA : DNA ratio.

Table 5 also shows that in the animals subjected to stalk section the weight and nucleic acid content of the CL maintained by oestrogen were greater than in the animals where the CL were maintained by hysterectomy (Group 6). Finally, the secretory capacity of the CL in the animals subjected to stalk section and treated with oestrogen on Day 20 of the cycle was apparently normal, and greater than that of the group subjected to stalk section, and hysterectomy (see Table 6). But this could have been due to the fact that in the hysterectomized group, a number of animals had infarcts involving the greater part of the pituitary tissue.

\section{DISGUSSION}

The results of these experiments can be summarized by posing four questions:

1. Is oestrogen luteotrophic because it acts on the hypothalamus, which in turn makes the pituitary secrete more luteotrophic hormone $(\mathrm{s})$ ?

It is known that oestrogen injections can cause a release of $\mathrm{LH}$ in sheep (Brown, Catt, Cumming, Goding, Kaltenbach \& Mole, 1969; Radford, Wheatley \& Wallace, 1969), and oestrogens can also augment the secretion of prolactin by the pituitary in several species (see review by Meites \& Nicoll, 1966). However, this is unlikely to be the principal luteotrophic action of oestrogen in the present experiments, because oestrogen was still effective in 
animals with stalk section where the hypothalamus no longer had any functional connections with the pituitary.

2. Is oestrogen luteotrophic because it has a direct action on the pituitary, causing it to secrete more luteotrophic hormone(s)?

Our experiments cannot exclude this possibility. However, up to $96 \%$ of pituitary tissue may become infarcted following stalk section (Adams, Daniel \& Pritchard, 1963) and even if more prolactin were secreted, this in itself would not be able to prolong the life of the GL in normal cycling ewes (Denamur \& Mauléon, 1963; Denamur, 1968).

3. Is oestrogen luteotrophic because it has a direct stimulatory action on the corpus luteum itself?

This also seems unlikely; oestrogen certainly cannot maintain the cL following hypophysectomy (Denamur \& Mauléon, 1963; Kaltenbach, Graber, Niswender \& Nalbandov, 1968). Moor (personal communication) has been unable to demonstrate a luteotrophic effect when small amounts of oestrogen are implanted directly into the CL. However, the fact that, in the present study, ewes on oestrogen therapy which had been subjected to stalk section had larger CL with a greater nucleic acid content on Day 20 than animals subjected to stalk section and hysterectomy might suggest that there is some direct effect.

4. Is oestrogen luteotrophic because in some way it interferes with the normal uterine luteolytic mechanism?

This would seem to be the most likely explanation. Not only can oestrogen, like hysterectomy, prolong the life of the cyclical $\mathrm{CL}$, but it can also prolong the life of the cL in animals with no functional pituitary connection.

In addition to its luteotrophic role, it is paradoxical that oestrogen can also be luteolytic in sheep; injections of 500 to $750 \mu \mathrm{g}$ on Days 11 and 12 of the cycle hastened the regression of the CL (Stormshak, Kelley \& Hawk, 1969). Since this luteolytic effect was abolished by hysterectomy, the inference must be that both the luteotrophic and luteolytic effects of oestrogen act primarily by way of the uterus. Chronic oestrogen treatment may so disturb endometrial development that luteolysin is never produced, whereas acute oestrogen treatment towards the end of the cycle may hasten the release of luteolysin.

As an experimental hypothesis, it seems reasonable to conclude that the four factors that prolong luteal life in sheep, namely pregnancy, oestrogen injections, LH infusion and hysterectomy, all do so by inhibiting uterine luteolysin production. Removal of the ultimate cause of luteal regression, the uterus, can arrest luteolysis even after it has already started on Day 15 (Moor et al., 1970), whereas pregnancy, oestrogen therapy or LH infusions have to be initiated several days beforehand if they are to produce luteotrophic effects (Moor, 1968; Karsch et al., 1969b; Stormshak et al., 1969). There are already several reasons for believing that the early sheep embryo exerts an anti-luteolytic rather than a luteotrophic effect (Moor, 1968; Short, 1969); the present investigation suggests that oestrogen may also interfere with uterine luteolysin production. It is possible that the luteotrophic effect of $\mathrm{LH}$ may be mediated by alterations in ovarian steroid secretion which in turn influence the production of luteolysin by the uterus. Whilst it is true that LH can have a direct luteotrophic action on the CL, producing a slight increase in progesterone secretion 
(Short et al., 1963; McCracken, Uno, Goding, Ichikawa \& Baird, 1969), it must, nevertheless, be regarded as an incomplete luteotrophin because it is unable to maintain the CL in hypophysectomized, hysterectomized sheep in the absence of exogenous prolactin (Denamur, Martinet \& Short, 1967).

\section{ACKNOWLEDGMENTS}

Our thanks are due to Miss S. A. Grieves, Miss J. Paly, Miss C. Claux and Mrs D. Drouet for skilled technical assistance, and to the Wellcome Trust for a grant to one of us (R.V.S.).

\section{REFERENCES}

Adams, J. H., Daniel, P. M. \& Pritchard, M. M. L. (1963) The effect of stalk section on the volume of the pituitary gland of the sheep. Acta endocr., Copenh. 43, Suppl 1,81.

Brown, J. M., Catt, K. J., Gumming, I. A., Goding, J. R., Kaltenbach, C. G. \& Mole, B. J. (1969) The release of luteinizing hormone in the ewe following oestradiol administration. $\mathcal{f}$. Physiol., Lond. 201, 98P.

Denamur, R. (1968) Formation and maintenance of corpora lutea in domestic animals. 7. Anim. Sci. 27, Suppl. 1, 163.

Denamur, R., Martinet, J. \& Short, R. V. (1966) Sécrétion de la progestérone par les corps jaunes de la brebis après hypophysectomie, section de la tige pituitaire et hystérectomie. Acta endocr., Copenh. 52, 72.

Denamur, R., Martinet, J. \& Short, R. V. (1967) Considérations sur les influences lutéotrophiques et luténlytiques chez la brebis. Archs Anat. Microsc. 56, Suppl. 339.

Denamur, R. \& Mauléon, P. (1963) Contrôle endocrinien de la persistance du corps jaune chez les ovins C.r. hebd. Séanc Acad. Sci., Paris, 257, 527.

Gaye, P. \& Denamur, R. (1970) Acides ribonucleiques et polyribosomes de la glande mammaire de la lapine au cours de la lactogènese induite par la prolactine. Biochim. biophys. Acta, 186, 99.

Ginther, O. J. (1967) Local utero-ovarian relationships. J. Anim. Sci. 26, 578.

Kaltendach, C. C., Graber, J. W., Niswender, G. D. \& Nalbandov, A. V. (1968) Luteotrophic properties of some pituitary hormones in nonpregnant and pregnant hypophysectomized ewes. Endocrinology, 82, 818.

Karsch, F. J., Noveroske, J. W., Roche, J. F. \& Nalbandov, A. V. (1969a) Minimal dose of Lh for luteal maintenance in ewes. F. Anim. Sci. 29, 192.

Karsch, F. J., Noveroske, J. W., Roche, J. F. \& Nalbandov, A. V. (1969b) Response to infused lh depends on age of ovine corpora lutea. F. Anim. Sci. 29, 192.

McCracken, J. A., Uno, A., Goding, J. R., Ichikawa, Y. \& Baird, D. T. (1969) The in-vivo effects of sheep pituitary gonadotrophins on the secretion of steroids by the autotransplanted ovary of the ewe. 7 . Endocr. 45, 425.

Meites, J. \& Nicoll, C. (1966) Adenohypophysis: prolactin. A. Rev. Physiol. 28, 57.

Moor, R. M. (1968) Effect of embryo on corpus luteum function. F. Anim. Sci. 27, Suppl. 1, 97.

Moor, R. M., Hay, M. F., Short, R. V. \& Rowson, L. E. A. (1970) The corpus luteum of the sheep: effect of uterine removal during luteal regression. F. Reprod. Fert. 21, 319.

PIPER, E. L. \& Foote, W. C. (1968) Ovulation and corpus luteum maintenance in ewes treated with $17 \beta$-oestradiol. F. Reprod. Fert. 16, 253.

Radford, H. M., Wheatley, I. S. \& Wallace, A. L. C. (1969) The effects of oestradiol benzoate and progesterone on secretion of luteinizing hormone in the ovariectomized ewe. $\mathcal{F}$. Endocr. 44, 135.

SCHOMberg, D. W., Coudert, S. P. \& ShorT, R. V. (1967) Effects of bovine luteinizing hormone and human chorionic gonadotrophin on the bovine corpus luteum in vivo. F. Reprod. Fert. 14, 277.

SHorT, R. V. (1969) Implantation and the maternal recognition of pregnancy. In: Foetal Autonomy, p. 2. Ciba Fdn Symp. Eds. G. E. W. Wolstenholme and M. O'Connor. Churchill, London.

Short, R. V., McDonald, M. F. \& Rowson, L. E. A. (1963) Steroids in the ovarian venous blood of ewes before and after gonadotrophic stimulation. 7. Endocr. 26, 155.

Stormshak, F., Kelley, H. E. \& HaWK, H. W. (1969) Suppression of ovine luteal function by $17 \beta$ estradiol. F. Anim. Sci. 29, 476. 